\title{
ДИАГНОСТИКА ЭКЗИСТЕНЦИАЛЬНОЙ ИСПОЛНЕННОСТИ: ОРИГИНАЛЬНАЯ РУССКОЯЗЫЧНАЯ ВЕРСИЯ ТЕСТА ЭКЗИСТЕНЦИАЛЬНЫХ МОТИВАЦИЙ
}

\author{
В.Б. ШУМСКИЙ ${ }^{a}$, Е.М. УКОЛОВАА \\ ${ }^{a}$ Национальный исследовательский университет «Высшая школа экономики», 101000, Россия, \\ Москва, ул. Мясницкая, д. 20 \\ ${ }^{b}$ ООО «Прайсвотерхаускуперс», 125047, Россия, Москва, ул. Бутырский вал, д. 10
}

\section{Резюме}

В статье представлены процесс и результаты разработки нового русскоязычного инструмента для измерения экзистенциальной исполненности, операционализирующего концепцию четырех фундаментальных экзистенциальных мотиваций А. Лэнгле. На основе феноменологических описаний конструктов и экспертной процедуры был разработан оригинальный русскоязычный набор из 94 утверждений, для валидизации которого были использованы две онлайн-выборки $(\mathrm{N}=818$ и $\mathrm{N}=215)$. С помощью иерархического кластерного анализа и конфирматорного факторного анализа с кросс-валидизацией на независимой выборке был получен набор из 36 утверждений, сгруппированных в 4 шкалы, соответствующие четырем фундаментальным экзистенциальным мотивациям, и 12 субшкал, соответствующих предпосылкам фундаментальных мотиваций. Шкалы опросника обладают приемлемой надежностью ( $\alpha$ от 0.79 до $0.88 ; \alpha=0.93$ для общего показателя). Конвергентная и дискриминантная валидность шкал опросника проверялась с помощью корреляционного и регрессионного анализа их связей с показателями эмоционального, социального и психологического благополучия, субъективного счастья, удовлетворенности жизнью, удовлетворенности базовых психологических потребностей, самооценки, интернальности, а также субъективного отчуждения и психопатологии. Результаты свидетельствуют о конвергентной валидности показателей экзистенциальной исполненности по отношению к индикаторам благополучия, опирающимся на другие теоретические подходы, а также о дискриминантной валидности шкал, соответствующих отдельным фундаментальным экзистенциальным мотивациям. Разработанная методика открывает новые возможности для эмпирических исследований в области экзистенциальной психологии и, в более широком контексте, в области психологии самореализации личности, психологического благополучия и удовлетворенности жизнью. Методика также может быть использована для решения практических задач психодиагностики, консультирования и психотерапии.

Ключевые слова: экзистенциальный анализ, фундаментальные экзистенциальные мотивации, свобода выбора, ценность жизни, самоценность, смысл, психометрика, конфирматорный факторный анализ, психологическое благополучие.

Исследование финансировалось в рамках государственной поддержки ведущих университетов Российской Федерации «5-100». Авторы благодарят А. Лэнгле за пристальное внимание к проекту и помощь в разработке набора утверждений опросника, М. Селину за помощь в сборе эмпирических данных. 


\section{Введение}

Согласно антропологической модели современного экзистенциального анализа, в познании человека необходимо сочетание гуманитарной и естественно-научной парадигм, дополнение традиционной для экзистенциальной психологии качественной исследовательской методологии количественными исследованиями (Лэнгле и др., 2014). На смену «экзистенциальной трагике» первой половины XX в. (Ж.-П. Сартр, М. Хайдегтер, К. Ясперс), понимающей человека как «заброшенного» против своей воли в этот мир и вынужденного в тревоге и потерянности вести свое бытие к смерти, пришли взгляды «позитивной» экзистенциальной философии и психологии, видящей человека как находящегося в неразрывных отношениях с окружающим миром, в которых он может переживать радость жизни, счастье глубокого межличностного общения с другими человеческими существами и осмысленность своего бытия (Шумский, 2016). Экзистенция понимается как имеющая определенную структуру, и степень субъективного переживания представленности этой структуры в жизни человека может быть оценена количественно посредством соответствующих опросников. В настоящей статье представлена разработка психометрического инструмента, в основе которого находится предложенная А. Лэнгле концепция фундаментальных экзистенциальных мотиваций (Лэнгле, 2005, 2006).

\section{Теоретические основания}

В самом общем виде термин «экзистенция» означает «специфи- чески человеческий способ бытия» (Франкл, 1997, с. 247), основной характеристикой которого является свобода выбора: «Свободное бытие человека мы называем также экзистенцией» (Ясперс, 2000, с. 46). Человек существует в пространстве возможностей, среди которых он выбирает: «Действительность человека - это возможности, а его бытие это бытие в модусе “я могу” (Frankl, 1982, S. 92). В концепции А. Лэнгле (Лэнгле, 2005, 2006) описаны фундаментальные мотивации (ФМ) человека, которые должны быть осуществлены для того, чтобы экзистенция состоялась (условия экзистенции). Базисом экзистенциальных мотиваций является способность человека принимать свободные решения.

Согласно А. Лэнгле, мотивация возникает в процессе диалогического обмена человека с миром, в котором присутствуют четыре фундаментальные данности бытия:

- мир с его условиями и возможностями;

- жизнь с ее отношениями и чувствами;

- бытие самим собой как уникальной, автономной личностью;

- будущее с присущим ему призывом к действию, к активному привнесению себя в более широкий контекст, в системы взаимосвязей, в которых человек находится и которые он создает.

В соответствии с первой ФМ для того, чтобы проживать «свободное бытие», человек стремится иметь различные возможности для выбора. Этому соответствует переживание «Я могу» («могу» = «имею возможности»), тремя предпосылками которого 
являются пространство, защищенность и опора. Человеку необходимо не только физическое пространство для жизни, но и психологическое пространство в семье, на работе, в обществе, а также определенная дистанция к самому себе, создающая пространство свободы по отношению к своим чувствам, желаниям, мыслям. Психологическую защищенность человек переживает, когда чувствует себя в безопасности, ощущает себя принятым другими людьми в социуме, в межличностных отношениях. Опора может быть найдена во внешнем мире - в законах природы, в структурах, закономерностях социальной жизни, и в самом себе - в своих способностях, знаниях, убеждениях, опыте.

Для выбора из возможностей, которые даны человеку в жизненных ситуациях, необходимы основания. Одним из оснований выступает качество жизни в результате реализации определенной возможности. Согласно второй ФМ, человек стремится к тому, чтобы ему нравилось жить, чтобы он мог радоваться жизни; предпосылками для этого являются соотнесенность, время и близость. В своем бытии-в-мире человек находится в различных соотнесениях в отношениях с другими людьми и с ценностями в мире, которыми могут быть идеи, вещи и т.д. Из соотнесенности с «иным» возникает переживание времени, которое подпитывает конкретные отношения, увеличивая их ценность, поскольку человек уделяет им время своей жизни. Время и психологическая близость к «иному» делают возможным возникновение эмоциональных волн, позволяя возникнуть чувствам удовольствия и радости, страдания и боли. Эмоции отражают субъективное восприятие человеком качества своей жизни.

Воспринимаемые возможности для выбора должны быть также соотнесены с нравственными установками человека и с общим содержанием его жизни. В соответствии с третьей ФМ человек в своей жизни стремится чувствовать самоценность и принимать аутентичные решения. Для этого необходимы три предпосылки: справедливое отношение, заинтересованное внимание и признание ценности. Каждому человеку важно, чтобы к нему относились справедливо, а также чтобы и он сам чувствовал, поступает он справедливо или нет. Благодаря способности различать «правильное» и «неправильное», человек может оценивать самого себя и предъявлять другим людям свои действия как адекватные и оправданные. Для справедливого отношения необходимо заинтересованное внимание - обнаружение собственного «Я» через заботливый взгляд на собственную индивидуальность, который укоренен в самоуважении и признании ценности бытия самим собой.

Выбор также должен быть соотнесен с будущим и с теми системами взаимосвязей, в которые человек включен и которые считает для себя важными (семья, профессия, родина и т.д.). Человек, в соответствии с четвертой ФМ, стремится понимать свое бытие в более широких контекстах и видеть в нем смысл. Для осуществления четвертой ФМ необходимы включенность во взаимосвязи, поле для деятельности и ценность в будущем. Благодаря системам взаимосвязей жизнь приобретает значимость, 
ценность и ясный порядок, эти системы открывают человеку поле для деятельности, ставят перед ним задачи, позволяя непрерывно раскрываться, устремляясь к будущему и к ценностям, которые предстоит в нем воплотить.

C каждой из фундаментальных экзистенциальных мотиваций связан принципиальный вопрос, который встает перед человеком:

- могу ли я быть тем, кто осуществляет свободный выбор?

- Нравится ли мне жить?

- Имею ли я право быть самим собой?

- В чем я вижу смысл?

Если человек чувствует, что может что-то сделать, если ему это нравится, если он также видит, что имеет на это право, и чувствует в этом поступке смысл, то тогда речь идет об истинно персональном, экзистенциальном волеизъявлении. Чем больше таких ситуаций как в повседневности, так и на более широком жизненном горизонте, тем выше экзистенциальная исполненность (ЭИ) человека. Более подробно теория четырех фундаментальных мотиваций представлена в работах А. Лэнгле (Лэнгле, 2005, 2006; Längle, 2016).

\section{Варианты опросника ТЭМ}

Первая версия «Теста экзистенциальных мотиваций» (ТЭМ), разработанная П. Экхардт на немецком языке (Eckhardt, 2001), состояла из 56 утверждений, которые оценивались респондентами по 6-ступенчатой шкале ответа. Утверждения опросника были отобраны на основе экспертной процедуры и анализа корреляций пунктов со шкалой; факторный анализ структуры не проводился. Теоретическая структура первой версии ТЭМ соответствует четырем фундаментальным экзистенциальным мотивациям, соответственно опросник имеет четыре шкалы (по 14 пунктов на каждую):

- первая ФМ - Фундаментальное доверие;

- вторая ФМ - Фундаментальная ценность;

- третья ФМ - Самоценность;

- четвертая ФМ - Смысл жизни.

Общий показатель экзистенциальной исполненности (ЭИ) рассчитывается как сумма показателей по четырем шкалам. На выборке из 1050 респондентов была продемонстрирована высокая внутренняя согласованность опросника $(\alpha=0.97)$. Существует также неопубликованный англоязычный вариант опросника ТЭМ, который не продемонстрировал ожидаемую четырехфакторную структуру (Launeanu, Längle, 2015).

Первая попытка адаптации ТЭМ для русскоязычной популяции была предпринята Ю.М. Корякиной (2010). Пункты опросника были переведены с немецкого языка, на выборке из 200 респондентов получена внутренняя согласованность четырех шкал в пределах 0.81-0.88, общего показателя - 0.95. Пилотажное исследование выявило предсказуемые прямые связи показателей ТЭМ с тестом смысложизненных ориентаций (СЖО) и обратные - с показателями тревожности теста Ч. Спилбергера, шкалой депрессии А. Бека и шкалой нейротизма из опросника EPI Г. Айзенка. Впоследствии была предложена вторая 
русскоязычная версия ТЭМ (Корякина, 2011), в которой 6 пунктов опросника были изменены с целью повышения их согласованности с суммарными баллами по шкалам. Это, однако, не привело к значительному изменению внутренней согласованности: на выборке, состоящей из 203 респондентов, была получена согласованность шкал в пределах 0.80-0.89, общего показателя - 0.96.

Несмотря на то что немецкоязычная и русскоязычная версии ТЭМ опубликованы достаточно давно, нам удалось обнаружить только одну публикацию об исследовании с использованием опросника. Русскоязычная версия ТЭМ применялась при изучении взаимосвязи экзистенциальной исполненности и эмоционального выгорания, которое оценивалось по опроснику В.В. Бойко (Efimowa, 2011). Были получены слабые обратные связи между шкалами двух методик.

Существенными ограничениями первых версий ТЭМ являются отсутствие информации о структурной валидизации методики, а также крайне ограниченный набор данных о ее конвергентной и дискриминантной валидности. Это сдерживает применение ТЭМ в научных исследованиях. Кроме того, отдельные формулировки утверждений, полученные путем перевода с немецкого языка, в русском варианте выглядели искусственно. Нами было принято решение о разработке новой русскоязычной методики, основанной на концепции фундаментальных экзистенциальных мотиваций А. Лэнгле. При разработке опросника мы не использовали утверждения из предыдущих версий ТЭМ; все пункты представляют собой не переводы, а заново сформулированные на русском языке утверждения.

Мы также пересмотрели принципы, по которым строились предыдущие версии ТЭМ. Поскольку они не прошли проверку внутренней структуры, оставалось неясным, в какой мере используемые в них утверждения действительно отражают для респондентов содержание той ФМ, к которой они отнесены теоретически. При разработке новой версии ТЭМ мы стремились к максимальной определенности теоретических оснований при формулировании утверждений теста. Мы сделали теоретическую структуру опросника более дифференцированной, используя для формулировки утверждений не только представления о фундаментальных экзистенциальных мотивациях, но и о предпосылках реализации ФМ (по три предпосылки на каждую мотивацию, см. таблицу 1).

Как показал опыт работы с предыдущими версиями ТЭМ (Ukolova et al., 2014), применение 6-ступенчатой шкалы Ликерта может приводить к высоким показателям асимметрии и эксцесса распределений ответов респондентов на отдельные пункты методики, поэтому в новой версии мы предпочли использовать 4-ступенчатую шкалу ответа, рассчитывая на то, что распределение ответов на пункты теста будет близким к нормальному, что облегчит в будущем процедуру стандартизации теста.

Таким образом, мы можем говорить о том, что, основываясь на концепции фундаментальных экзистенциальных мотиваций А. Лэнгле, мы фактически создали новый оригинальный русскоязычный опросник. 
Таблица 1

Теоретическая структура оригинальной русскоязычной версии опросника ТЭМ: фундаментальные экзистенциальные мотивации (ФМ) и предпосылки их реализации

\begin{tabular}{|c|c|c|c|c|}
\hline$\Phi \mathbf{M}$ & $\begin{array}{c}\text { Содержание } \\
\text { мотивации }\end{array}$ & \multicolumn{3}{|c|}{ Предпосылки реализации мотивации } \\
\hline Первая ФМ & $\begin{array}{l}\text { Возможности } \\
\text { бытия-в-мире }\end{array}$ & Пространство & Защищенность & Опора \\
\hline Вторая ФМ & Ценность жизни & Соотнесенность & Время & Близость \\
\hline Третья ФМ & Самоценность & $\begin{array}{c}\text { Справедливое } \\
\text { отношение }\end{array}$ & $\begin{array}{c}\text { Заинтересованное } \\
\text { внимание }\end{array}$ & $\begin{array}{c}\text { Признание } \\
\text { ценности }\end{array}$ \\
\hline Четвертая ФМ & Смысл & $\begin{array}{c}\text { Включенность } \\
\text { во взаимосвязи }\end{array}$ & $\begin{array}{c}\text { Поле } \\
\text { деятельности }\end{array}$ & $\begin{array}{c}\text { Ценность в } \\
\text { будущем }\end{array}$ \\
\hline
\end{tabular}

В настоящей статье представлены результаты разработки и валидизации новой русскоязычной версии Теста экзистенциальных мотиваций, предназначенной для субъективной оценки респондентом степени реализации в своей жизни фундаментальных экзистенциальных мотиваций и степени экзистенциальной исполненности своего бытия-в-мире.

\section{Методика}

\section{Въцорка и процедура}

В исследовании использованы две онлайн-выборки добровольцев, которые рекрутировались через социальные сети и заполняли опросники анонимно. Основная выборка $(\mathrm{N}=818)$, использованная для первичной валидизации опросника, включала $31.1 \%$ мужчин и $68.9 \%$ женщин в возрасте от 18 до 75 лет (до 20 лет - 15.2\%, 21-30 лет - 62.3\%, 31-40 лет - 14.9\%, 41-50 лет $4.4 \%, 50$ лет и старше - 3.2\%). Выборка кросс-валидизации ( $\mathrm{N}=215)$ включала $37.2 \%$ мужчин и $62.8 \%$ женщин в возрасте от 16 до 69 лет (до 20 лет - 9.8\%, 21-30 лет - 55.4\%, 31-40 лет - 22.8\%, 41-50 лет $9.8 \%, 50$ лет и старше $-2.3 \%)$.

\section{Инструменть}

Тест әкзистенциальных мотиваций. Опираясь на описания А. Лэнгле (Лэнгле, 2005, 2006; Längle, 2016; Längle et al., 2003), мы сформулировали набор утверждений, отражающих феноменальное содержание 12 предпосылок фундаментальных экзистенциальных мотиваций (см. таблицу 2). Исходный набор утверждений дорабатывался и корректировался в ходе групповых дискуссий авторов и фокус-групп с участием студентов магистратуры, изучающих экзистенциальный анализ. Для валидизации содержаний полученный набор из 93 утверждений (от семи до девяти на каждую предпосылку) был предложен 13 экспертам, прошедшим не менее четырех лет обучения в области экзистенциально-аналитического консультирования и психотерапии. Экспертов просили оценить, 
какую из 12 предпосылок ФМ отражает каждое утверждение; в качестве показателя согласованности для каждого утверждения использовалась доля экспертов, которые пришли к единому мнению. Респонденты обеих выборок заполняли набор из 93 утверждений, которые оценивались по 4-балльной шкале (от 1 «Совершенно не соответствует» до $4-\ll$ Полностью соответствует»).

Для оценки дискриминантной и конвергентной валидности опросника ТЭМ был использован ряд дополнительных методик, измеряющих различные аспекты психологического благополучия и неблагополучия.
Часть респондентов основной выборки $(\mathrm{N}=104)$ заполняли три дополнительные методики:

1. Опросник К. Киза Mental Health Continuum - Short Form (Keyes, 2009) в адаптации Е.H. Осина (ŻemojtelPiotrowska et al., under review). Методика разработана на основе модели психологического благополучия К. Киза и К. Рифф и включает три шкалы: эмоциональное благополучие (частота переживания позитивных эмоций), социальное благополучие (включенность в социальные связи) и психологическое благополучие (6 компонентов, согласно модели К. Рифф и К. Киза).

Таблица 2

\section{Примеры пунктов опросника ТЭМ}

\begin{tabular}{|c|c|}
\hline \multirow{3}{*}{ Первая ФМ } & $\begin{array}{l}\text { Пространство }\left(1_{\text {фмпр }}\right): \text { Мне достаточно пространства для жизни и } \\
\text { развития }\end{array}$ \\
\hline & 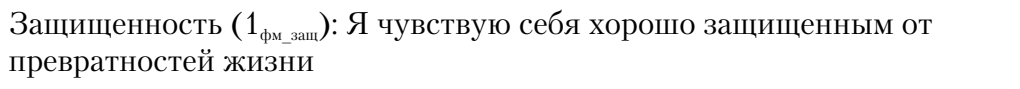 \\
\hline & 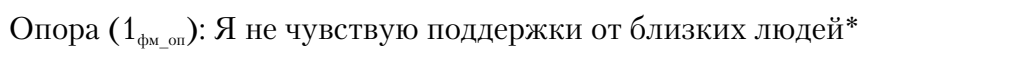 \\
\hline \multirow{3}{*}{ Вторая ФМ } & Соотнесенность $\left(2_{\text {фм_сотн }}\right):$ Я легко вступаю в контакт с людьми \\
\hline & $\begin{array}{l}\text { Близость }\left(2_{\text {фм_блз }}\right) \text { : Поддержание близких отношений вызывает у меня } \\
\text { трудности и разочарования }\end{array}$ \\
\hline & $\begin{array}{l}\text { Время }\left(2_{\text {фм_вемя }}\right) \text { : Мне постоянно не хватает времени на то, что я считаю } \\
\text { для себя действительно важным* }\end{array}$ \\
\hline \multirow{3}{*}{ Третья ФМ } & $\begin{array}{l}\text { Заинтересованное внимание }\left(3_{\text {фм_внмм }}\right) \text { : Меня не занимает мой } \\
\text { внутренний мир* }\end{array}$ \\
\hline & $\begin{array}{l}\text { Справедливое отношение }\left(3_{\text {фм_спав }}\right) \text { : Я считаю, что жизнь справедлива } \\
\text { ко мне }\end{array}$ \\
\hline & Признание ценности $\left(3_{\text {фм_ценн }}\right)$ : Мне не за что себя уважать* \\
\hline \multirow{3}{*}{ Четвертая ФМ } & $\begin{array}{l}\text { Включенность во взаимосвязи }\left(4_{\text {фмвключ }}\right): \text { Я чувствую себя частью чего- } \\
\text { то важного }\end{array}$ \\
\hline & 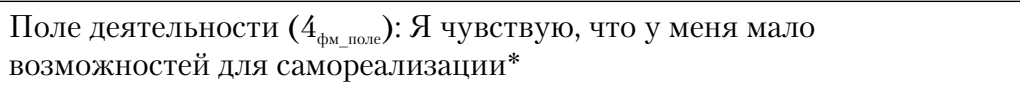 \\
\hline & Ценность в будущем ( $\left.4_{\text {фмбуд }}\right)$ : Я не знаю, чего хочу от жизни* \\
\hline
\end{tabular}

* - обратные вопросы. 
2. Шкала удовлетворенности базовых психологических потребностей Э. Диси и Р. Райана в адаптации Т.О. Гордеевой и Е.Н. Осина (Ягіяев и др., 2015) измеряет удовлетворенность потребностей в автономии, компетентности и связанности, описанных в теории самодетерминации Р. Райана и Э. Диси.

3. Шкала самооценки М. Розенберга в адаптации А. А. Бодалева и В. В. Столина (2002).

Другие респонденты основной выборки $(\mathrm{N}=114)$ заполняли Сокращенный многофакторный опросник для исследования личности (СМОЛ) (Зайцев, 1981). Эта русскоязычная версия опросника MiniMult, полученная путем сокращения теста MMPI, включает 8 контентных шкал и 3 шкалы достоверности.

Респонденты выборки кросс-валидизации в дополнение к ТЭМ заполняли следующий набор методик:

1. Шкала удовлетворенности жизнью Э. Динера в адаптации Д.А. Леонтьева (Осин, Леонтьев, 2008).

2. Шкала субъективного счастья С. Любомирски в адаптации Д.А. Леонтьева (Там же).

3. Опросник «Локус контроля» Дж. Роттера в адаптации В.А. Ядова (Клюковкин, Ладыгин, 2007).

4. Опросник субъективного отчуждения для взросльх (ОСОтч-В) (Осин, 2007), опирающийся на теорию экзистенциального невроза С. Мадди.

Мы предполагали, что общий показатель ТЭМ и все четыре шкалы ФМ будут прямо связаны с индикаторами благополучия (счастье, удовлетворенность жизнью, удовлетворенность базовых психологических потребностей) и позитивного функционирования (самооценка, внутренний локус контроля) и обратно с индикаторами психопатологии и отчуждения. Поскольку, с теоретической точки зрения, содержание отдельных показателей психологического благополучия более тесно соотносится с содержанием отдельных ФМ (потребность в автономии - с первой ФМ и третьей ФМ, потребность в компетентности с первой ФМ, потребность в связанности, эмоциональное благополучие - со второй ФМ, самооценка, отчуждение - с третьей ФМ, социальное благополучие - с четвертой ФМ) и т.д., мы ожидали получить также и дополнительные данные о дискриминантной валидности шкал ФМ.

\section{Результаты}

\section{Структурная валидность опросника}

Согласно экспертным оценкам, исходный набор утверждений показал достаточно высокую содержательную валидность $(\mathrm{M}=0.70, \mathrm{SD}=0.17)$; лишь для 15 утверждений из 93 показатель согласованности оценок экспертов был ниже 0.5.

Для отбора утверждений в итоговый вариант опросника мы использовали данные основной выборки. Поскольку связи между утверждениями, согласно теоретической модели, должны были иметь иерархическую структуру (12 предпосылок, сгруппированных в четыре ФМ), для выделения групп пунктов, отражающих каждую предпосылку, мы использовали иерархический кластерный анализ 
(метод Уорда, квадратичная метрика Евклида на стандартизованных пунктах; обратные утверждения были предварительно инвертированы). В полученной структуре выделились четыре больших кластера, которые содержательно соответствовали четырем ФМ.

На основе кластерной модели мы выделили 23 однородные группы утверждений, каждая из которых включала от трех до шести пунктов, и проинтерпретировали их содержательно в терминах предпосылок ФМ. Далее, для каждой из 12 предпосылок ФМ мы стремились отобрать по три утверждения-индикатора, которые удовлетворяли бы трем критериям: а) обладали достаточно высокой содержательной валидностью (по данным экспертных оценок), б) не содержали пар с похожими формулировками, в) образовывали надежные шкалы как на уровне отдельных предпосылок, так и на уровне ФМ (так как мы изначально предполагали, что шкалы четырех ФМ должны обладать более высокой диагностической ценностью, чем субшкалы предпосылок ФМ, мы отдавали предпочтение надежности первых).

Структурная валидность полученного набора утверждений проверялась при помощи конфирматорного факторного анализа в пакете Mplus 7.4 (алгоритм оценки WLSMV, переменные задавались как порядковые). На первом шаге мы стремились получить простую структуру из 12 первичных факторов, соответствующих предпосылкам ФМ (модель 1). Для повышения дискриминантной валидности субшкал предпосылок ФМ по итогам анализа индексов модификации мы исключали утверждения, демонстрировавшие высокие перекрестные нагрузки, и заменяли их другими, опираясь на перечисленные выше критерии, после чего модель повторно оценивалась. Когда индексы соответствия модели достигли показателей, свидетельствующих о хорошем соответствии данным, мы проверили иерархические модели с четырьмя факторами второго порядка, соответствующими ФМ (модель 2), и с единым фактором третьего порядка, соответствующим общему уровню экзистенциальной исполненности (модель 3). Для сравнения вложенных моделей использовалась функция Mplus DIFFTEST.

Полученные показатели соответствия структурных моделей представлены в таблице 3. Исходная модель из 12 первичных факторов показала хорошее соответствие данным. Модель из четырех вторичных факторов соответствовала данным значимо хуже, однако ее индексы соответствия свидетельствовали о приемлемом соответствии данным, что позволяло принять эту модель с учетом ее более высокой объяснительной ценности. Модель 3 с единым фактором ЭИ значимо не отличалась по показателям соответствия от модели 2 с четырьмя факторами ФМ.

Для кросс-валидизации полученной структуры мы использовали данные второй выборки. На выборке кросс-валидизации модель из 12 первичных факторов вновь показала хорошее соответствие данным (CFI > 0.95, RMSEA < 0.06). Модель из 4 вторичных факторов не сошлась. Источником проблем была эмпирически неопределенная нагрузка второй 
Таблица 3

Показатели соответствия структурных моделей Теста экзистенциальных мотиваций

\begin{tabular}{|c|c|c|c|c|c|c|}
\hline \multirow[t]{2}{*}{ Модель } & \multicolumn{4}{|c|}{ Индексы соответствия } & \multicolumn{2}{|c|}{$\begin{array}{c}\text { Сравнение с } \\
\text { предыдущей } \\
\text { моделью }\end{array}$} \\
\hline & $\chi^{2}$ & df & CFI & $\begin{array}{c}\text { RMSEA } \\
\text { (90\%-й доверительный } \\
\text { интервал) }\end{array}$ & $\Delta x^{2}$ & $\Delta \mathrm{df}$ \\
\hline \multicolumn{7}{|c|}{ Основная выборка $(\mathrm{N}=818)$} \\
\hline 1. 12 факторов & $1686.11^{*}$ & 528 & 0.947 & $0.052(0.049-0.055)$ & -- & -- \\
\hline 2. 4 фактора 2-го уровня & $2302.49^{*}$ & 576 & 0.921 & $0.061(0.058-0.063)$ & $548.29 *$ & 48 \\
\hline 3. 1 фактор 3-го уровня & $2273.50^{*}$ & 578 & 0.922 & $0.060(0.057-0.062)$ & 0.98 & 2 \\
\hline \multicolumn{7}{|c|}{ Выборка кросс-валидизации (N = 215) } \\
\hline 1. 12 факторов & $904.47^{*}$ & 528 & 0.952 & $0.058(0.051-0.064)$ & -- & -- \\
\hline 2’. 4 фактора 2-го уровня & $1148.47^{*}$ & 577 & 0.928 & $0.068(0.062-0.074)$ & $256.19^{*}$ & 49 \\
\hline 3'. 1 фактор 3-го уровня & $1142.70^{*}$ & 579 & 0.929 & $0.067(0.062-0.073)$ & 0.81 & 2 \\
\hline
\end{tabular}

$* p<0.05$.

предпосылки (время) на фактор второй мотивации. Для идентификации модели мы зафиксировали этот параметр, указав значение нагрузки, полученное на основной выборке. Как и на основной выборке, полученная модель (2') значимо отличалась от модели 1 $\left(\chi^{2}=256.19\right.$, df $\left.=49, p<0.001\right)$, но демонстрировала приемлемое соответствие данным, а созданная на ее основе модель 3' с единым фактором третьего порядка значимо не отличалась от модели 2'.

Bce нагрузки утверждений на шкалы были значимыми и достаточно высокими как на основной выборке $(0.49<\lambda<0.95)$, так и на выборке кросс-валидизации $(0.36<\lambda<0.94)$. Параметры итоговой модели 3 на основной выборке представлены на рисунке 1. Результаты структурной валидизации итоговой версии опросника свидетельствуют о хорошем соответствии эмпирической структуры опросника его теоретической модели и хорошей воспроизводимости этого результата на независимой выборке.

\section{Надежность показателей опросника}

Для оценки внутренней согласованности (одномоментной надежности) показателей опросника мы использовали альфа-коэффициент Кронбаха, который рассчитывался на обеих выборках. Полученные показатели внутренней согласованности (см. таблицу 4) достаточно высоки, чтобы использовать баллы по общему показателю ЭИ и показателям четырех ФМ в диагностических целях, а баллы по субшкалам опросника - в исследовательских целях. 
Параметры итоговой модели 3 на основной выборке

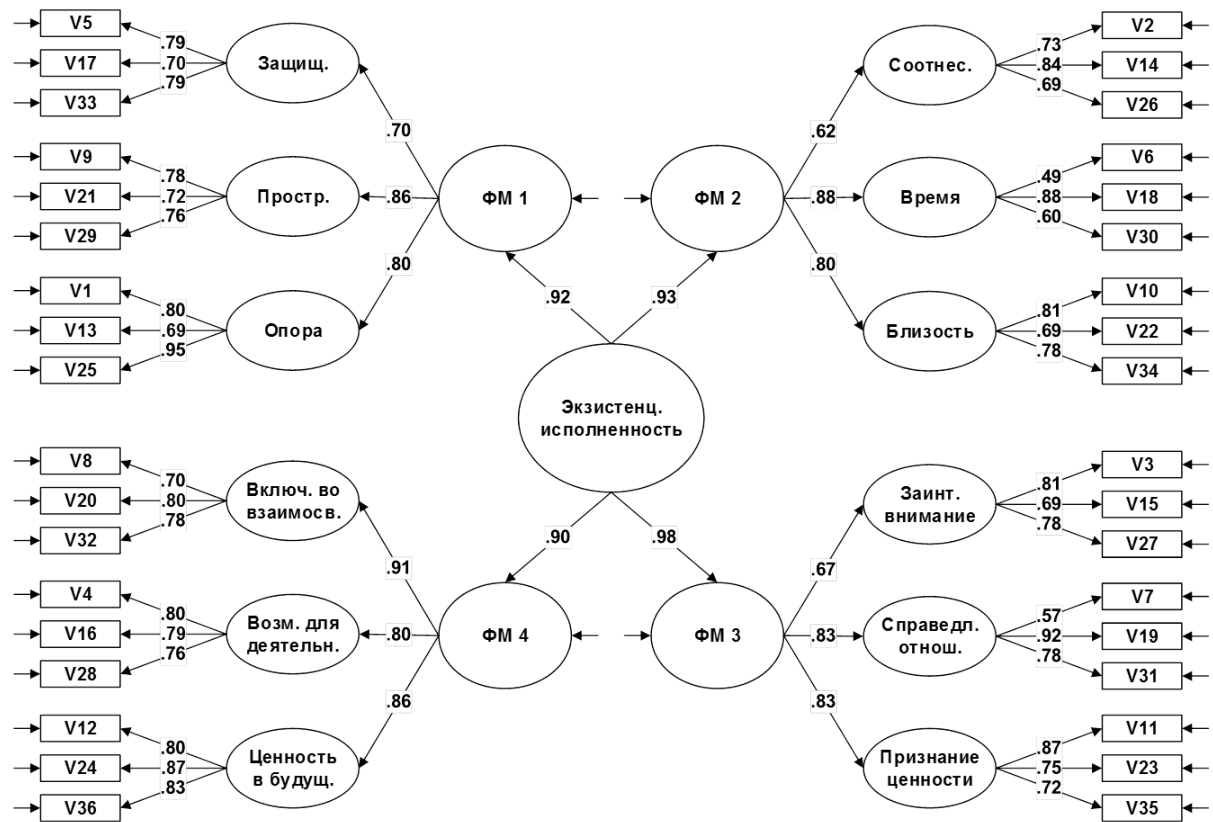

Примечание. Нумерация утверждений соответствует Приложению; нагрузки обратных утверждений инвертированы.

Распределения по шкалам четырех ФМ и общему показателю ЭИ были близки к нормальному виду на обеих выборках: значения асимметрии и эксцесса не превышали 0.6 по модулю, что позволяет применять параметрические статистики для анализа полученных баллов.

\section{Гендерные и возрастные различия в показателях ТЭМ}

Поскольку связи баллов опросника с демографическими характеристиками респондентов важны для диагностического применения методики, мы изучили их на объединенной выборке (использованные выборки были сходными по демогра- фическому составу, а средние показатели по шкалам опросника между ними различались весьма слабо: d Коэна $<0.25)$.

Ряд гендерных различий оказался значимым (см. таблицу 5): результаты свидетельствовали о более высоком уровне экзистенциальной исполненности у женщин по сравнению с мужчинами по показателям второй ФМ (соотнесенность, близость) и третьей ФМ (заинтересованное внимание, справедливое отношение), а также по общему показателю ЭИ и субшкале опоры из первой ФМ. Однако по размеру эффекта почти все эти различия оказались достаточно слабыми.

Связи с возрастом имели монотонный характер и свидетельствовали о 
Таблица 4

Показатели внутренней согласованности (альфа Кронбаха) шкал и субшкал опросника

\begin{tabular}{|l|c|c|}
\hline \multicolumn{1}{|c|}{ Субшкала } & Основная выборка & Выборка кросс-валидизации \\
\hline Общий показатель ЭИ & 0.93 & 0.94 \\
\hline Первая ФМ & 0.84 & 0.85 \\
\hline Защищенность & 0.73 & 0.75 \\
\hline Пространство & 0.74 & 0.76 \\
\hline Опора & 0.77 & 0.80 \\
\hline Вторая ФМ & 0.79 & 0.82 \\
\hline Соотнесенность & 0.73 & 0.78 \\
\hline Время & 0.63 & 0.61 \\
\hline Близость & 0.72 & 0.72 \\
\hline Третья ФМ & 0.79 & 0.79 \\
\hline Заинтересованное внимание & 0.64 & 0.62 \\
\hline Справедливое отношение & 0.71 & 0.70 \\
\hline Признание ценности & 0.75 & 0.75 \\
\hline Четвертая ФМ & 0.87 & 0.88 \\
\hline Включенность во взаимосвязи & 0.76 & 0.75 \\
\hline Поле деятельности & 0.75 & 0.79 \\
\hline Ценность в будущем & 0.82 & 0.87 \\
\hline
\end{tabular}

более высоких показателях экзистенциальной исполненности у представителей зрелого возраста по сравнению с молодежью. Однако по магнитуде эти связи также были небольшими. В целом эти результаты свидетельствуют о том, что гендер и возраст слабо связаны с показателями экзистенциальной исполненности и не требует разработки дифференцированных норм для представителей разных демографических групп.

\section{Конвергентная валидность шкал ТЭМ}

Для оценки конвергентной валидности шкал ТЭМ мы рассчитывали корреляционные связи (по Пирсону) показателей четырех ФМ и общего показателя ЭИ с показателями психологического благополучия и психопатологии на основной выборке и выборке кросс-валидизации.

Корреляции показателей ТЭМ с показателями благополучия по опросникам МНС, самооценки, а также удовлетворенности базовых потребностей представлены в таблице 6. В целом, все четыре показателя ФМ и общий показатель ЭИ продемонстрировали умеренные и высокие связи с показателями благополучия.

Связи показателей ТЭМ со шкалами методики СМОЛ представлены в таблице 7. Общий показатель 
Таблии а 5

Связи показателей ТЭМ с полом и возрастом респондентов (объединенная выборка)

\begin{tabular}{|c|c|c|c|c|}
\hline Шкала (субшкала) & $\begin{array}{c}\text { Мужчины } \\
(\mathrm{N}=288), \\
\text { M (SD) }\end{array}$ & $\begin{array}{c}\text { Женщины } \\
(\mathrm{N}=647) \\
\text { M (SD) }\end{array}$ & $\begin{array}{c}\text { Гендерные } \\
\text { различия, } \\
\text { d Коэна }\end{array}$ & $\begin{array}{c}\text { Связь } \\
\text { с возрастом, } \\
\text { р Спирмена }\end{array}$ \\
\hline ЭИ общий показатель & $101.25(17.11)$ & $104.27(17.30)$ & $0.17^{*}$ & $0.09 * *$ \\
\hline Первая ФМ & $24.34(5.06)$ & $24.74(5.06)$ & 0.08 & 0.04 \\
\hline Опора & $8.66(2.17)$ & $9.21(2.12)$ & $0.26^{* * *}$ & 0.02 \\
\hline Защищенность & $7.91(2.10)$ & $7.67(1.93)$ & -0.12 & 0.01 \\
\hline Пространство & $7.73(2.18)$ & $7.85(2.10)$ & 0.05 & 0.06 \\
\hline Вторая ФМ & $23.88(5.19)$ & $25.18(5.02)$ & $0.26^{* * *}$ & $0.10^{* *}$ \\
\hline Соотнесенность & $7.78(2.18)$ & $8.11(2.19)$ & $0.15^{*}$ & $0.07^{*}$ \\
\hline Близость & $8.94(2.25)$ & $9.63(2.12)$ & $0.32^{* * *}$ & 0.02 \\
\hline Время & $7.16(2.06)$ & $7.44(2.15)$ & 0.13 & $0.14^{* * *}$ \\
\hline Третья ФМ & $27.47(4.45)$ & $28.59(4.45)$ & $0.25^{* * *}$ & $0.08^{*}$ \\
\hline Заинтересованное внимание & $9.57(1.78)$ & $10.42(1.59)$ & $0.52 * * *$ & -0.02 \\
\hline Справедливое отношение & $8.85(1.96)$ & $9.15(1.85)$ & $0.16^{*}$ & 0.05 \\
\hline Признание ценности & $9.04(2.20)$ & $9.04(2.16)$ & 0.00 & $0.12^{* * *}$ \\
\hline Четвертая ФМ & $25.41(5.75)$ & $25.74(5.59)$ & 0.06 & $0.09^{*}$ \\
\hline Поле деятельности & $9.09(2.20)$ & $9.07(2.02)$ & -0.01 & $-0.07^{*}$ \\
\hline $\begin{array}{l}\text { Включенность во } \\
\text { взаимосвязи }\end{array}$ & $7.24(2.19)$ & $7.51(2.23)$ & 0.12 & $0.16^{* * *}$ \\
\hline Ценность в будущем & $9.08(2.52)$ & $9.18(2.38)$ & 0.04 & $0.11^{* * *}$ \\
\hline
\end{tabular}

${ }^{*} p<0.05,{ }^{* *} p<0.01, * * * p<0.001$; для d Коэна указан уровень значимости двустороннего критерия Стьюдента.

ЭИ и все показатели четырех ФМ продемонстрировали значимые отрицательные связи с контентными шкалами СМОЛ. Для контроля социальной желательности мы также рассчитали частные корреляции шкал ТЭМ и СМОЛ при контроле шкал достоверности СМОЛ (L, F, K). Все полученные связи общего показателя с контентными шкалами, за исключением связи со шкалой гипомании, остались значимыми: таким образом, лишь связи со шкалой гипомании полностью объясняются эффектами социальной желательности. Наиболее сильными оказались обратные связи показателей ТЭМ со шкалами депрессии и психастении; умеренные отрицательные связи получены со шкалами шизоидности, паранойяльности и истерии; слабой оказалась связь со шкалой ипохондрии.

Эти результаты свидетельствуют о том, что экзистенциальная исполненность обратно связана с психопатологией. Следует, однако, отметить, 
Таблица 6

Корреляции показателей ТЭМ с показателями психологического благополучия ( $\mathrm{N}=104)$

\begin{tabular}{|c|c|c|c|c|c|c|c|c|c|c|c|c|}
\hline & 1 & 2 & 3 & 4 & 5 & 6 & 7 & 8 & 9 & 10 & 11 & 12 \\
\hline \multicolumn{13}{|l|}{$\begin{array}{l}\text { 1. Общий показатель } \\
\text { ЭИ }\end{array}$} \\
\hline 2. Первая ФМ & 0.82 & & & & & & & & & & & \\
\hline 3. Вторая ФМ & 0.85 & 0.61 & & & & & & & & & & \\
\hline 4. Третья ФМ & 0.87 & 0.64 & 0.69 & & & & & & & & & \\
\hline 5. Четвертая ФМ & 0.85 & 0.59 & 0.59 & 0.64 & & & & & & & & \\
\hline $\begin{array}{l}\text { 6. Эмоциональное } \\
\text { благополучие }\end{array}$ & 0.70 & 0.55 & 0.62 & 0.63 & 0.56 & & & & & & & \\
\hline $\begin{array}{l}\text { 7. Социальное } \\
\text { благополучие }\end{array}$ & 0.55 & 0.42 & 0.44 & 0.44 & 0.55 & 0.56 & & & & & & \\
\hline $\begin{array}{l}\text { 8. Психологическое } \\
\text { благополучие }\end{array}$ & 0.68 & 0.46 & 0.65 & 0.57 & 0.61 & 0.69 & 0.63 & & & & & \\
\hline $\begin{array}{l}\text { 9. Потребность в } \\
\text { автономии }\end{array}$ & 0.77 & 0.73 & 0.64 & 0.72 & 0.57 & 0.54 & 0.38 & 0.48 & & & & \\
\hline $\begin{array}{l}\text { 10. Потребность в } \\
\text { компетентность }\end{array}$ & 0.73 & 0.54 & 0.64 & 0.58 & 0.70 & 0.56 & 0.38 & 0.67 & 0.51 & & & \\
\hline $\begin{array}{l}\text { 11. Потребность в } \\
\text { связанности }\end{array}$ & 0.71 & 0.64 & 0.68 & 0.64 & 0.49 & 0.57 & 0.46 & 0.56 & 0.66 & 0.55 & & \\
\hline 12. Самооценка & 0.77 & 0.60 & 0.63 & 0.74 & 0.64 & 0.55 & 0.33 & 0.54 & 0.61 & 0.65 & 0.54 & \\
\hline Альфа Кронбаха & 0.93 & 0.77 & 0.78 & 0.80 & 0.87 & 0.83 & 0.82 & 0.85 & 0.70 & 0.73 & 0.78 & 0.81 \\
\hline
\end{tabular}

Примечание. Все связи значимы на уровне $p<0.001$.

что показатели внутренней согласованности для ряда шкал СМОЛ оказались невысокими; для достоверной оценки связей ЭИ с показателями психопатологии необходимо использование более совершенных и психометрически валидных инструментов, таких как MMPI-2 (Рассказова и др., 2013).

Связи показателей ЭИ с показателями субъективного благополучия, интернального локуса контроля и отчуждения на выборке кросс-валидизации представлены в таблице 8 . Уровень экзистенциальной исполненности прямо связан с интерналь- ностью, с переживанием субъективного счастья и удовлетворенности жизнью и обратно - с показателями отчуждения (наиболее сильно - с показателем отчуждения от самого себя).

\section{Дискриминантная валидность шкал ТЭМ}

Для более подробного анализа общей дисперсии показателей четырех фундаментальных экзистенциальных мотиваций (по ТЭМ) с показателями других методик мы использовали множественный линейный 
Таблица 7

Корреляции показателей ТЭМ с индикаторами психопатологии по тесту СМОЛ ( $\mathrm{N}=104)$

\begin{tabular}{|l|c|c|c|c|c|c|c|}
\hline & $\begin{array}{c}\text { Общий } \\
\text { показале } \\
\text { ЭИ }\end{array}$ & $\begin{array}{c}\text { Первая } \\
\text { ФМ }\end{array}$ & $\begin{array}{c}\text { Вторая } \\
\text { ФМ }\end{array}$ & $\begin{array}{c}\text { Третья } \\
\text { ФМ } \\
\text { Четвертая } \\
\text { ФМ }\end{array}$ & $\begin{array}{c}\text { Общий } \\
\text { показатель } \\
\text { ЭИ, } \\
\text { контроль } \\
\text { СЖК }\end{array}$ & $\boldsymbol{\alpha}$ \\
\hline $\mathrm{L}$ & $0.34^{* * *}$ & $0.40^{* * *}$ & $0.26^{* *}$ & $0.25^{* *}$ & $0.29^{* *}$ & -- & 0.25 \\
\hline $\mathrm{F}$ & $-0.36^{* * *}$ & $-0.33^{* * *}$ & $-0.33^{* * *}$ & $-0.38^{* * *}$ & $-0.24^{*}$ & -- & 0.53 \\
\hline $\mathrm{K}$ & $0.48^{* * *}$ & $0.49^{* * *}$ & $0.42^{* * *}$ & $0.42^{* * *}$ & $0.38^{* * *}$ & -- & 0.59 \\
\hline $\mathrm{HS}$ & $-0.45^{* * *}$ & $-0.48^{* * *}$ & $-0.37^{* * *}$ & $-0.35^{* * *}$ & $-0.40^{* * *}$ & $-0.23^{*}$ & 0.72 \\
\hline $\mathrm{D}$ & $-0.77^{* * *}$ & $-0.70^{* * *}$ & $-0.68^{* * *}$ & $-0.66^{* * *}$ & $-0.68^{* * *}$ & $-0.72^{* * *}$ & 0.64 \\
\hline $\mathrm{Hy}$ & $-0.53^{* * *}$ & $-0.50^{* * *}$ & $-0.47^{* * *}$ & $-0.41^{* * *}$ & $-0.48^{* * *}$ & $-0.49^{* * *}$ & 0.42 \\
\hline $\mathrm{Pd}$ & $-0.63^{* * *}$ & $-0.64^{* * *}$ & $-0.51^{* * *}$ & $-0.59^{* * *}$ & $-0.49^{* * *}$ & $-0.55^{* * *}$ & 0.55 \\
\hline $\mathrm{Pa}$ & $-0.60^{* * *}$ & $-0.58^{* * *}$ & $-0.59^{* * *}$ & $-0.51^{* * *}$ & $-0.44^{* * *}$ & $-0.46^{* * *}$ & 0.56 \\
\hline $\mathrm{Pt}$ & $-0.74^{* * *}$ & $-0.69^{* * *}$ & $-0.69^{* * *}$ & $-0.62^{* * *}$ & $-0.63^{* * *}$ & $-0.62^{* * *}$ & 0.82 \\
\hline $\mathrm{Sc}$ & $-0.66^{* * *}$ & $-0.65^{* * *}$ & $-0.60^{* * *}$ & $-0.57^{* * *}$ & $-0.52^{* * *}$ & $-0.49^{* * *}$ & 0.83 \\
\hline $\mathrm{Ma}$ & $-0.35^{* * *}$ & $-0.40^{* * *}$ & $-0.31^{* *}$ & $-0.27^{* *}$ & $-0.27^{* *}$ & -0.01 & 0.59 \\
\hline$\alpha$ & 0.95 & 0.86 & 0.84 & 0.85 & 0.88 & -- & \\
\hline
\end{tabular}

Примечание. L - Ложь, F - Достоверность, K - Коррекция, HS - Ипохондрия, D Депрессия, Нy - Истерия, Pd - Психопатия, $\mathrm{Pa}-$ Паранойяльность, $\mathrm{Pt}-$ Психастения, Sc Шизоидность, Ма - Гипомания, $\alpha$ - альфа Кронбаха.

${ }^{*} p<0.05,{ }^{* *} p<0.01,{ }^{* * *} p<0.001$.

регрессионный анализ (предварительно мы проверили переменные на мультиколлинеарность: для всех четырех шкал ФМ показатели tolerance превышали 0.4 , а показатели VIF не превышали 2.5, что позволяет использовать эти переменные как предикторы совместно в регрессионном анализе - см.: Tabachnick, Fidell, 2007). В связи с тем, что большая часть шкал СМОЛ показала недостаточно высокую надежность, мы не использовали эту методику на данном этапе анализа. Полученные результаты представлены в таблице 9.
Все регрессионные модели оказались статистически достоверными. Доля дисперсии в показателях шкал других методик, объясненная четырьмя шкалами ТЭМ, составила от 29 до 64\%. Наиболее тесные связи ТЭМ были получены с показателями удовлетворенности базовых потребностей, самооценки, субъективного счастья и удовлетворенности жизнью, психологического благополучия по модели К. Рифф (опросник МНС$\mathrm{SF}$ ), а также отчуждения (общего отчуждения и отчуждения от самого себя). 
Таблица 8

Корреляции показателей ТЭМ со шкалами других методик на выборке кросс-валидизации $(\mathrm{N}=\mathbf{2 1 5})$

\begin{tabular}{|l|c|c|c|c|c|c|c|c|c|c|c|c|c|c|}
\hline & 1 & 2 & 3 & 4 & 5 & 6 & 7 & 8 & 9 & 10 & 11 & 12 & 13 & 14 \\
\hline 1 & & & & & & & & & & & & & & \\
\hline 2 & 0.86 & & & & & & & & & & & & & \\
\hline 3 & 0.84 & 0.62 & & & & & & & & & & & & \\
\hline 4 & 0.86 & 0.69 & 0.61 & & & & & & & & & & & \\
\hline 5. & 0.88 & 0.65 & 0.63 & 0.69 & & & & & & & & & & \\
\hline 6 & 0.68 & 0.67 & 0.49 & 0.58 & 0.58 & & & & & & & & & \\
\hline 7 & 0.76 & 0.67 & 0.60 & 0.67 & 0.66 & 0.68 & & & & & & & & \\
\hline 8 & 0.44 & 0.35 & 0.28 & 0.41 & 0.46 & 0.36 & 0.32 & & & & & & & \\
\hline 9 & -0.73 & -0.63 & -0.56 & -0.68 & -0.64 & -0.56 & -0.59 & -0.49 & & & & & & \\
\hline 10 & -0.54 & -0.43 & -0.34 & -0.54 & -0.54 & -0.38 & -0.40 & -0.47 & 0.74 & & & & & \\
\hline 11 & -0.50 & -0.42 & -0.33 & -0.51 & -0.47 & -0.37 & -0.41 & -0.51 & 0.78 & 0.58 & & & & \\
\hline 12. & -0.58 & -0.50 & -0.50 & -0.56 & -0.45 & -0.46 & -0.47 & -0.35 & 0.85 & 0.49 & 0.61 & & & \\
\hline 13 & -0.56 & -0.54 & -0.50 & -0.47 & -0.44 & -0.46 & -0.44 & -0.26 & 0.79 & 0.41 & 0.42 & 0.64 & & \\
\hline 14 & -0.74 & -0.61 & -0.57 & -0.67 & -0.69 & -0.57 & -0.64 & -0.40 & 0.86 & 0.55 & 0.54 & 0.69 & 0.67 & \\
\hline$\alpha$ & 0.94 & 0.85 & 0.82 & 0.79 & 0.88 & 0.87 & 0.87 & 0.75 & 0.95 & 0.82 & 0.84 & 0.86 & 0.88 & 0.87 \\
\hline
\end{tabular}

Примечание. 1 - Общий показатель ЭИ, 2 - Первая ФМ, 3 - Вторая ФМ, 4 - Третья ФМ, 5 - Четвертая ФМ, 6 - Удовлетворенность жизнью, 7 - Субъективное счастье, 8 Интернальность, 9 - Общее отчуждение, 10 - Отчуждение от работы, 11 - Отчуждение от общества, 12 - Отчуждение от отношений, 13 - Отчуждение от семьи, 14 - Отчуждение от себя, $\alpha-$ альфа Кронбаха. Все связи значимы на уровне $p<0.001$.

Все четыре ФМ продемонстрировали уникальный вклад в показатель субъективного счастья, однако показатель удовлетворенности жизнью был связан лишь с первой ФМ, исполненность которой наиболее тесно связана с объективными условиями жизни, и, слабее, с четвертой ФМ. Уникальными предикторами эмоционального (гедонистического) благополучия оказались показатели второй ФМ и третьей ФМ. Социальное эвдемоническое благополучие, связанное с наличием включенности в значимые широкие соци- альные контексты, предсказывал только показатель четвертой ФМ. Психологическое эвдемоническое благополучие предсказывали показатели второй ФМ и четвертой ФМ.

Удовлетворенность базовой потребности в автономии была связана с исполненностью первой ФМ и третьей ФМ, в компетентности четвертой ФМ и второй ФМ, в связанности - со второй ФМ, первой ФМ и третьей ФМ. Показатель самооценки по шкале М. Розенберга, отражающий удовлетворенность собой, предсказывали показатели 
Таблица 9

Результаты множественного регрессионного анализа

\begin{tabular}{|l|c|l|l|l|l|l|}
\hline \multirow{2}{*}{ Зависимая переменная } & \multirow{2}{*}{$\mathrm{N}$} & \multirow{2}{*}{$R^{2}$} & \multicolumn{4}{|c|}{ Коэффициент $\beta$} \\
\cline { 5 - 7 } & & & 1 ФМ & 2 ФМ & 3 ФМ & 4 ФМ \\
\hline Эмоциональное благополучие & 104 & $0.49^{* * *}$ & 0.13 & $0.27^{* *}$ & $0.25^{* *}$ & 0.17 \\
\hline Социальное благополучие & 104 & $0.33^{* * *}$ & 0.08 & 0.12 & 0.05 & $0.40^{* * *}$ \\
\hline Психологическое благополучие & 104 & $0.51^{* * *}$ & -0.07 & $0.41^{* * *}$ & 0.11 & $0.34^{* * *}$ \\
\hline Потребность в автономии & 104 & $0.64^{* * *}$ & $0.41^{* * *}$ & 0.13 & $0.35^{* * *}$ & 0.02 \\
\hline Потребность в компетентности & 104 & $0.57^{* * *}$ & 0.06 & $0.31^{* * *}$ & 0.04 & $0.46^{* * *}$ \\
\hline Потребность в связанности & 104 & $0.56^{* * *}$ & $0.29^{* *}$ & $0.36^{* * *}$ & $0.23^{* *}$ & -0.04 \\
\hline Самооценка & 104 & $0.61^{* * *}$ & 0.12 & 0.13 & $0.43^{* * *}$ & $0.22^{*}$ \\
\hline Удовлетворенность жизнью & 215 & $0.50^{* * *}$ & $0.45^{* * *}$ & 0.02 & 0.13 & $0.19^{*}$ \\
\hline Субъективное счастье & 215 & $0.58^{* * *}$ & $0.28^{* * *}$ & $0.14^{*}$ & $0.24^{* * *}$ & $0.23^{* *}$ \\
\hline Внутренний локус контроля & 215 & $0.24^{* * *}$ & 0.03 & -0.09 & $0.20^{*}$ & $0.36^{* * *}$ \\
\hline Общее отчуждение & 215 & $0.55^{* * *}$ & $-0.19^{* *}$ & -0.10 & $-0.34^{* * *}$ & $-0.22^{* *}$ \\
\hline Отчуждение от работы & 215 & $0.35^{* * *}$ & -0.05 & 0.10 & $-0.33^{* * *}$ & $-0.34^{* * *}$ \\
\hline Отчуждение от общества & 215 & $0.29^{* * *}$ & -0.09 & 0.07 & $-0.35^{* * *}$ & $-0.21^{*}$ \\
\hline Отчуждение от отношений & 215 & $0.36^{* * *}$ & -0.16 & $-0.21^{* *}$ & $-0.34^{* * *}$ & 0.02 \\
\hline Отчуждение от семьи & 215 & $0.34^{* * *}$ & $-0.31^{* * *}$ & $-0.23^{* *}$ & -0.10 & -0.02 \\
\hline Отчуждение от себя & 215 & $0.56^{* * *}$ & $-0.14^{*}$ & -0.11 & $-0.28^{* * *}$ & $-0.34^{* * *}$ \\
\hline
\end{tabular}

${ }^{*} p<0.05,{ }^{* *} p<0.01,{ }^{* * *} p<0.001$.

третьей ФМ и, слабее, четвертой ФМ. Показатель интернальности был связан с третьей ФМ и четвертой ФМ. Показатели отчуждения были наиболее тесно связаны с третьей ФМ. Отчуждение от работы и отчуждение от общества, учитывающее степень включенности в широкие социальные контексты, были связаны с третьей ФМ и четвертой ФМ, отчуждение в межличностных отношениях - со второй ФМ и третьей ФМ, отчуждение от семьи - с первой ФМ и второй ФМ, отчуждение от себя - с первой ФМ, третьей ФМ и четвертой ФМ.

\section{Обсуждение}

Широкое распространение экзистенциальной психологии и развитие экзистенциального консультирования и психотерапии требует разработки психометрических инструментов для количественного изучения этой реальности. Однако сложность этой задачи заключается в том, что конструкты экзистенциальной философии лежат на высоком уровне обобщения и их крайне трудно операционализировать, не прибегая к философскому языку. Экзистенциальный анализ А. Лэнгле стремится 
описать реальность человеческого бытия с опорой на феноменологический метод и при помощи терминов обыденного языка, понятных представителям любой культуры («пространство», «защищенность», «близость», «справедливость» и др.), создавая возможность разработки психометрических инструментов.

К сожалению, разработанные до сих пор варианты методик, опирающихся на идеи экзистенциального анализа, строились с опорой на теорию и эксплораторные методы, без более строгой проверки с помощью современной методологии конфирматорного факторного анализа. Кроме того, русскоязычные версии этих методик были получены путем перевода с немецкого языка и зачастую содержали не вполне удачные формулировки. Разработанная нами оригинальная русскоязычная методика, вероятно, не позволяет охватить все богатство феноменальной реальности человеческого бытия в коротком наборе вопросов, но выгодно отличается от предыдущих аналогов краткостью набора утверждений, их понятностью для русскоязычных респондентов, более высокой надежностью шкал, а также теоретически и эмпирически валидной структурой. Надежность шкал методики достаточно высока как для исследовательских, так и для психодиагностических целей, а субшкалы могут быть полезны главным образом для исследователей.

Экзистенциальная исполненность характеризует бытие человека в целом, это показатель качества жизни. Специфика этого показателя заключается в его опоре на экзистенциальный подход. Данные о конвергентной валидности свидетельствуют о высокой согласованности показателя ЭИ с показателями психологического благополучия, опирающимися на другие, хорошо разработанные теоретические подходы, такие как модель психологического благополучия К. Рифф и К. Киза, а также теория самодетерминации Э. Диси и Р. Райана. Данные о дискриминантной валидности шкал методики ТЭМ в значительной степени согласуются с нашими ожиданиями, основанными на теоретическом анализе конструктов, описывающих сходную феноменологию, но вытекающих из контекста разных психологических школ. Выраженные обратные связи ЭИ с психопатологией убедительно свидетельствуют о валидности ЭИ как показателе психологического здоровья и благополучия, а также в перспективе позволяют разработать критерии для применения ТЭМ в качестве скринингового инструмента для выявления психических нарушений.

Основным ограничением проведенного исследования является специфический характер использованной выборки (анонимные добровольцы, заполнявшие опросник онлайн). Согласно сложившемуся в последние годы консенсусу, процедура сбора данных онлайн не ставит под сомнение валидность полученных результатов, но все же ограничивает репрезентативность выборки (см., например: Леонтьев, Осин, 2011). Разработанные нормы, а также представленные выше данные о связях показателей ЭИ с гендером и возрастом можно считать предварительными.

Разработанная методика открывает новые возможности для эмпирических исследований в русле экзи- 
стенциальной психологии и - более широко - психологии самореализации личности, психологического благополучия и удовлетворенности жизнью. Методика может быть использована для решения как исследовательских, так и прикладных, практических психодиагностических задач. Вместе с тем необходимы дальнейшие исследования для проверки ее критериальной валидности в различных ситуациях и стандартизация на репрезентативных выборках. С нашей точки зрения, проделанная работа может иметь и методическую ценность: при разра- ботке новой версии опросника ТЭМ мы стремились преодолеть ограничения предыдущих версий, разработанных на немецком, английской и русском языках. Теоретически обоснованная иерархическая структура опросника и описанные нами методические шаги его разработки могут быть предложены в качестве основы для создания методик, операционализирующих концепцию фундаментальных экзистенциальных мотиваций А. Лэнгле применительно к разным системам жизненных отношений человека, а также к разным культурным контекстам.

\section{Литература}

Бодалев, А. А., Столин, В. В. (2002). Общая психодиагностика. СПб.: Речь.

Зайцев, В. П. (1981). Вариант психологического теста Mini-Mult. Психологический журнал, 2(3), $118-123$

Клюковкин, В. Н., Ладыгин, Ю. И. (2007). Личность руководителя и мотивация его деятельности. Бийск: Изд-во Алтайского государственного технического университета.

Корякина, Ю. М. (2010). Адаптация опросника экзистенциальных мотиваций «ТЭМ» (Тест экзистенциальных мотиваций) А. Лэнгле, П. Экхард. Экзистенциальный анализ, 2, 139-148.

Корякина, Ю. М. (2011). Опросник экзистенциальных мотиваций «ТЭМ» А. Лэнгле, П. Экхард. Экзистенциальный анализ, 3, 169-179.

Леонтьев, Д. А., Осин, Е. Н. (2011). Методологические и методические вопросы эмпирического изучения и диагностики личностного потенциала. В кн. Д. А. Леонтьев (ред.), Личностный потенциал: структура и диагностика (с. 404-423). М.: Смысл.

Лэнгле, А. (2005). Person. Экзистенциально-аналитическая теория личности. М.: Генезис.

Лэнгле, А. (2006). Что движет человеком? Экзистенииально-аналитическая теория эмоций. М.: Генезис.

Лэнгле, А., Уколова, Е. М., Шумский, В. Б. (2014). Современный экзистенциальный анализ. М.: Логос.

Осин, Е. Н. (2007). Смыслоутрата как переживание отчуждения: структура и диагностика (Кандидатская диссертация, Московский государственный университет имени М.В. Ломоносова, Москва).

Осин, Е. Н., Леонтьев, Д. А. (2008). Апробация русскоязычных версий двух шкал экспресс-оценки субъективного благополучия. В кн. Материаль III Всероссийского социологического конгресса. М.: Институт социологии РАН/Российское общество социологов. Режим доступа: http://publications.hse.ru/en/chapters/78753840 
Рассказова, Е. И., Богомаз, С. А., Дорфман, Л. Я., Леонтьев, Д. А., Неяскина, Ю. Ю., Сулимина, О. В., Четошникова, Е. В. (2013). Психометрические характеристики русскоязычной версии ММРІ-2. Психологические исследования: электрон. науч. журн., 6(29), 2. Режим доступа: http://psystudy.ru

Франкл, В. (1997). Доктор и душа. СПб.: Ювента.

Шумский, В.Б. (2016). Экзистенциальная психология и психотерапия. М.: Юрайт.

Ягіяєв, І. І., Осін, Є. М., Гордєєва, Т. О. (2015). Російськомовна адаптація методики задоволеності базових психологічных потреб на украпнській та російській выбірці. В кн. Вісник Кам'янець-Подільського національного університету імені Івана Огієнка: Психологічні науки (вып. 7, с. 182-190). Кам'янець-Подільський: Медобори-2006.

Ясперс, К. (2000). Введение в философию. Минск: Изд-во ЕГУ «Пропилеи».

Eckhardt, P. (2001). Skalen zur Erfassung existentieller Motivation, Selbstwert und Sinnerleben [Scales measuring existential motivations, selfworth, and experience of meaning]. Existenzanalyse, 18(1), 35-39.

Efimowa, I. N. (2011). Diagnostik und Beratung in der Burnout-Prophylaxe mithilfe des TEM [Assessment and Counselling in Burnout Prophylaxis with help of TEM]. Existenzanalyse, 28(1), $94-97$.

Frankl, V. E. (1982). Ärztliche Seelsorge [The Doctor and the Soul]. Wien: Deuticke.

Keyes, C. L. M. (2009). Atlanta: Brief description of the mental health continuum short form (MHC-SF). Retrieved from http://www.sociology.emory.edu/ckeyes/

Längle, A. (2016). Existenzanalyse - Existentielle Zugänge in der Psychotherapie [Existential Analysis - Existential Introduction to Psychotherapy]. Wien: Facultas.

Längle, A., Orgler, C., \& Kundi, M. (2003). The Existence Scale: A new approach to assess the ability to find personal meaning in life and to reach existential fulfillment. European Psychotherapy, 4(1), $135-151$.

Launeanu, M., \& Längle, A. (2015). Recent validation studies of the Test for Existential Motivations (TEM). Paper presented at the World Congress for Existential Psychotherapy (London, May 1417, 2015).

Tabachnick, B. L., \& Fidell L. S. (2007). Using multivariate statistics (5th ed.). Boston, MA: Pearson Education.

Ukolova, E. M., Shumskiy V. B., \& Osin, E. N. (2014). TEMIR - A test to measure existential motivations in interpersonal relationships: Factorial structure, reliability and validity. Existenzanalyse, 31(2), 8-13.

Żemojtel-Piotrowska, M., Piotrowski, J., Osin, E. N. Cieciuch, J., Adams, B. G., et al. (на рецензировании). Mental Health Continuum- Short Form: The structure and application for cross-cultural studies. Journal of Clinical Psychology. 


\section{Бланк и ключи опросника ТЭМ}

Приложение

Уважаемый участник опроса, пожалуйста, оцените с помощью шкалы, насколько каждое утверждение соответствует Вашей жизни:

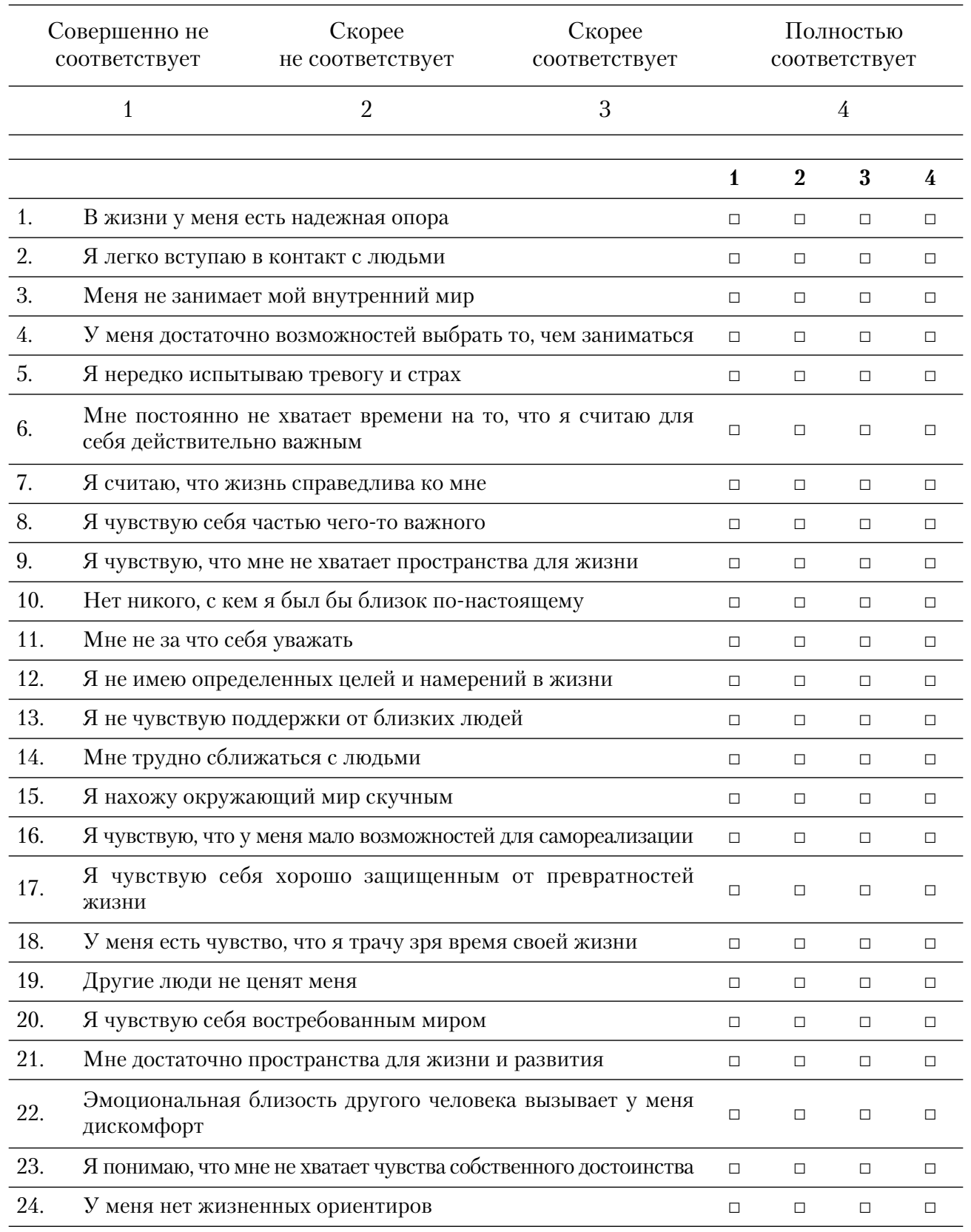




\begin{tabular}{|c|c|c|c|c|c|}
\hline & & 1 & 2 & 3 & 4 \\
\hline 25. & Мне не на что опереться в жизни & $\square$ & $\square$ & $\square$ & $\square$ \\
\hline 26. & $\begin{array}{l}\text { Я предпочитаю сохранять дистанцию по отношению к другим } \\
\text { людям }\end{array}$ & $\square$ & $\square$ & $\square$ & $\square$ \\
\hline 27. & Меня не сильно интересует внутренний мир других людей & $\square$ & $\square$ & $\square$ & $\square$ \\
\hline 28. & Мир для меня - широкое поле возможностей & $\square$ & $\square$ & $\square$ & $\square$ \\
\hline 29. & Я чувствую, что обстоятельства моей жизни давят на меня & $\square$ & $\square$ & $\square$ & $\square$ \\
\hline 30. & $\begin{array}{l}\text { Бо́льшую часть времени я занимаюсь тем, что считаю действи- } \\
\text { тельно важным }\end{array}$ & $\square$ & $\square$ & $\square$ & $\square$ \\
\hline 31. & Я чувствую, что другие люди несправедливо ко мне относятся & $\square$ & $\square$ & $\square$ & $\square$ \\
\hline 32. & Я нашел свое место в жизни & $\square$ & $\square$ & $\square$ & $\square$ \\
\hline 33. & Обычно я чувствую себя небезопасно & $\square$ & $\square$ & $\square$ & $\square$ \\
\hline 34. & $\begin{array}{l}\text { Поддержание близких отношений вызывает у меня трудности } \\
\text { и разочарования }\end{array}$ & $\square$ & $\square$ & $\square$ & $\square$ \\
\hline 35. & Я ценю себя за то, какой я есть & $\square$ & $\square$ & $\square$ & $\square$ \\
\hline 36. & Я не знаю, чего хочу от жизни & $\square$ & $\square$ & $\square$ & $\square$ \\
\hline
\end{tabular}

\section{Ключи:}

\begin{tabular}{|c|c|c|c|c|c|c|}
\hline \multirow{2}{*}{ Шкала } & \multirow{2}{*}{ Субшкала } & \multirow{2}{*}{$\begin{array}{c}\text { Номера } \\
\text { вопросов }\end{array}$} & \multirow{2}{*}{$\begin{array}{l}\text { Нормы, } \\
\text { М (SD) }\end{array}$} & \multicolumn{3}{|c|}{ Диапазоны баллов } \\
\hline & & & & Низкие & Средние & Высокие \\
\hline \multirow{3}{*}{$1 \Phi \mathrm{M}$} & Опора & $1,13^{*}, 25^{*}$ & \multirow{3}{*}{$\begin{array}{l}24.54 \\
(5.06)\end{array}$} & \multirow{3}{*}{$9-19$} & \multirow{3}{*}{$20-29$} & \multirow{3}{*}{$30-36$} \\
\hline & Защищенность & $5^{*}, 17,33^{*}$ & & & & \\
\hline & Пространство & $9^{*}, 21,29^{*}$ & & & & \\
\hline \multirow{3}{*}{$2 \Phi \mathrm{M}$} & Соотнесенность & $2,14^{*}, 26^{*}$ & \multirow{3}{*}{$\begin{array}{l}24.53 \\
(5.11)\end{array}$} & \multirow{3}{*}{$9-19$} & \multirow{3}{*}{$20-29$} & \multirow{3}{*}{$30-36$} \\
\hline & Время & $6^{*}, 18^{*}, 30$ & & & & \\
\hline & Близость & $10^{*}, 22^{*}, 34^{*}$ & & & & \\
\hline \multirow{3}{*}{$3 Ф \mathrm{M}$} & Заинтересованное внимание & $3^{*}, 15^{*}, 27^{*}$ & \multirow{3}{*}{$\begin{array}{l}28.03 \\
(4.45)\end{array}$} & \multirow{3}{*}{$9-23$} & \multirow{3}{*}{$24-32$} & \multirow{3}{*}{$33-36$} \\
\hline & Справедливое отношение & $7,19^{*}, 31^{*}$ & & & & \\
\hline & Признание ценности & $11^{*}, 23^{*}, 35$ & & & & \\
\hline \multirow{3}{*}{$4 \Phi \mathrm{M}$} & Возможности для деятельности & $4,16^{*}, 28$ & \multirow{3}{*}{$\begin{array}{l}25.58 \\
(5.67)\end{array}$} & \multirow{3}{*}{$9-19$} & \multirow{3}{*}{$20-31$} & \multirow{3}{*}{$32-36$} \\
\hline & Включенность во взаимосвязи & $8,20,32$ & & & & \\
\hline & Ценность в будущем & $12^{*}, 24^{*}, 36^{*}$ & & & & \\
\hline $\begin{array}{c}\text { Общий } \\
\text { показа- } \\
\text { тель } \\
\text { ЭИ }\end{array}$ & Все 36 пунктов & $\begin{array}{l}102.76 \\
(17.21)\end{array}$ & $36-85$ & $86-119$ & $120-144$ & \\
\hline
\end{tabular}

Обратные пункты отмечены звездочкой. Варианты ответов на прямые вопросы оцениваются по шкале 123 4, на обратные - по шкале 432 1. После этого для подсчета баллов необходимо 
просуммировать баллы по 9 пунктам, входящим в каждую шкалу. Общий показатель ЭИ сумма баллов по всем четырем шкалам ФМ. Нормы даны для объединенной онлайн-выборки $(\mathrm{N}=923)$ со взвешиванием по гендеру; низкий и высокий диапазоны выделены на основе процентильных баллов, соответствующих 1 стандартному отклонению от среднего.
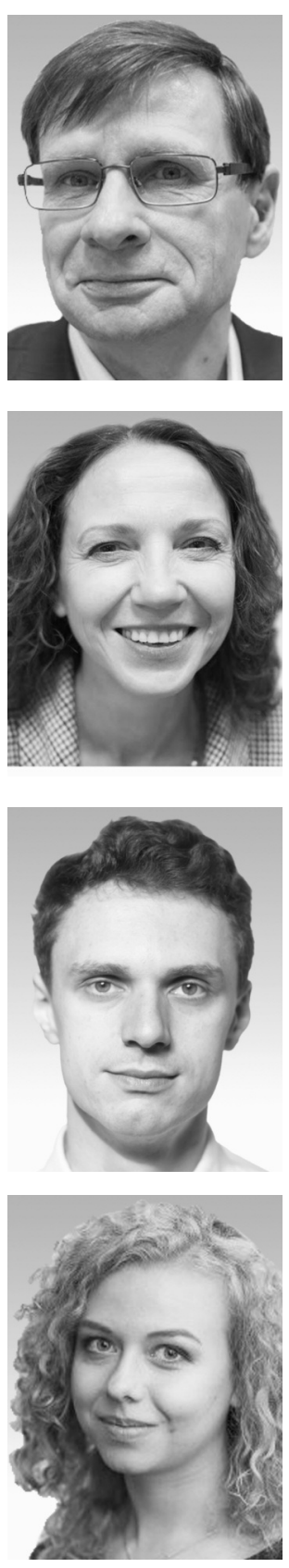

Шумский Владимир Борисович

Кандидат психологических наук, доцент кафедры психологии личности департамента психологии факультета социальных наук, Национальный исследовательский университет «Высшая школа экономики».

Сфера интересов: экзистенциальная психология, психология личности, психологическое консультирование, психотерапия.

Контакты: existenzanalyse@yandex.ru

Уколова Елена Михайловна

Кандидат психологических наук, старший преподаватель кафедры психологии личности департамента психологии факультета социальных наук, Национальный исследовательский университет «Высшая школа экономики».

Сфера интересов: психология личности и индивидуальности, методология преподавания психологии, экзистенциальная психология и психотерапия, детская и подростковая психология и психотерапия. Контакты: eukolova@hse.ru

Осин Евгений Николаевич

Кандидат психологических наук, доцент департамента психологии и ведущий научный сотрудник Международной лаборатории позитивной психологии личности и мотивации, Национальный исследовательский университет «Высшая школа экономики».

Сфера интересов: экзистенциальная психология, позитивная психология, психометрика.

Контакты: evgeny.n.osin@gmail.com

Лупандина Яна Дмитриевна

Магистр психологии, специалист по подбору персонала ООО «Прайсвотерхаускуперс».

Сфера интересов: экзистенциальная психология, психологическое тестирование, оценка персонала.

Контакты: yanalupandina@mail.ru 


\title{
Measuring Existential Fulfillment: An Original Russian Version of Test of Existential Motivations
}

\author{
V.B. Shumsky ${ }^{a}$, E.M. Ukolova ${ }^{a}$, E.N. Osin ${ }^{a}$, Y.D. Lupandina ${ }^{b}$ \\ ${ }^{a}$ National Research University Higher School of Economics, 20 Myasnitskaya Str., Moscow, 101000, \\ Russian Federation \\ ${ }^{b}$ OOO Pricewaterhouse Coopers Advisory White Square Office Center, 10 Butyrsky Val, Moscow, 125047, \\ Russian Federation
}

\begin{abstract}
The paper presents a new Russian-language instrument measuring existential fulfillment within the theory of 4 existential fundamental motivations developed by A. Längle. Based on phenomenological descriptions of the constructs and expert discussions, we developed an original Russian-language set of 94 items, which was validated in 2 online samples $(\mathrm{N}=818$ and $\mathrm{N}=215$ ). Using hierarchical cluster analysis and confirmatory factor analysis with cross-validation in an independent sample, we arrived at a set of 36 items grouped into 4 scales and 12 subscales (corresponding to theoretical prerequisites of fundamental motivations). The scales demonstrate acceptable reliability ( in the .79-.88 range, .93 for the general score). We sought evidence of convergent and discriminant validity of the scales by using correlational and multiple regression analyses of their associations with indicators of emotional, social, and psychological well-being, subjective happiness, satisfaction with life, basic psychological need satisfaction, self-esteem, internal locus of control, as well as alienation and psychopathology. The findings support the convergent validity of existential fulfillment indicators against well-being measures based on different theoretical approaches, as well as discriminant validity of specific existential fundamental motivation scales. The new instrument opens up new possibilities for empirical research in the field of existential psychology and, in a broader context, the psychology of selfactualization, well-being, and life satisfaction. The questionnaire can also be used in assessment, counseling, and psychotherapy.
\end{abstract}

Keywords: existential analysis, existential fundamental motivations, choice autonomy, value of life, self-value, meaning, psychometrics, confirmatory factor analysis, psychological well-being.

\section{References}

Bodalev, A. A., \& Stolin, V. V. (2002). Obshchaya psikhodiagnostika [General psychodiagnostics]. Saint Petersburg: Rech'.

Eckhardt, P. (2001). Skalen zur Erfassung existentieller Motivation, Selbstwert und Sinnerleben [Scales measuring existential motivations, selfworth, and experience of meaning]. Existenzanalyse, 18(1), 35-39. (in German)

Efimowa, I. N. (2011). Diagnostik und Beratung in der Burnout-Prophylaxe mithilfe des TEM [Assessment and Counselling in Burnout Prophylaxis with help of TEM]. Existenzanalyse, 28(1), 94-97. (in German) 
Frankl, V. E. (1982). Ärztliche Seelsorge [The Doctor and the Soul]. Wien: Deuticke. (in German)

Frankl, V. (1997). Doktor i dusha [The doctor and the soul]. Saint Petersburg: Yuventa. (Transl. of: Frankl, V. (1955). The doctor and the soul: From psychotherapy to logotherapy. New York: Alfred A. Knopf).

Jaspers, K. (2000). Vvedenie v filosofiyu [Introdaction to filosophy]. Minsk: EGU "Propilei”. (Transl. of: Jaspers, K. (1950). Einfuhrung in die Philosophie [Introdaction to filosophy]. Zurich: Artemis. (in German)).

Keyes, C. L. M. (2009). Atlanta: Brief description of the mental health continuum short form (MHC-SF). Retrieved from http://www.sociology.emory.edu/ckeyes/

Klyukovkin, V. N., \& Ladygin, Yu. I. (2007). Lichnost' rukovoditelya i motivatsiya ego deyatel'nosti [Lider's personality and motivation of his activity]. Biysk: Altai State Technical University.

Koryakina, Yu. M. (2010). Adaptatsiya oprosnika ekzistentsial'nykh motivatsii “TEM" (Test ekzistentsial'nykh motivatsii) A. Längle, P. Eckhardt [Adaptation of the questionnaire of existential motivation "TEM" (Test of existential motivation)]. Ekzistentsial'nyi Analiz, 2, 139-148.

Koryakina, Yu. M. (2011). Oprosnik ekzistentsial'nykh motivatsii “TEM” A. Längle, P. Eckhardt [Test of existential motivation "TEM" A. Längle, P. Eckhardt]. Ekzistentsial'nyi Analiz, 3, 169-179.

Längle, A. (2005). Person: Ekzistentsial'no-analiticheskaya teoriya lichnosti [Person: Existential-analytical theory of personality]. Moscow: Genezis.

Längle, A. (2006). Chto dvizhet chelovekom? Ekzistentsial'no-analiticheskaya teoriya emotsii [What drives a man? Existential-analytical theory of emotions]. Moscow: Genezis.

Längle, A. (2016). Existenzanalyse - Existentielle Zugänge in der Psychotherapie [Existential Analysis - Existential Introduction to Psychotherapy]. Wien: Facultas. (in German)

Längle, A., Orgler, C., \& Kundi, M. (2003). The Existence Scale: A new approach to assess the ability to find personal meaning in life and to reach existential fulfillment. European Psychotherapy, 4(1), $135-151$.

Längle, A., Ukolova, E. M., \& Shumskii, V. B. (2014). Sovremennyi ekzistentsial'nyi analiz [Contemporary existential analysis]. Moscow: Logos.

Launeanu, M., \& Längle, A. (2015). Recent validation studies of the Test for Existential Motivations (TEM). Paper presented at the World Congress for Existential Psychotherapy (London, May 1417, 2015).

Leontiev, D. A., \& Osin, E. N. (2011). Metodologicheskie i metodicheskie voprosy empiricheskogo izucheniya i diagnostiki lichnostnogo potentsiala [Methodological and methodical issues of empirical research and diagnostics of personal potential]. In D. A. Leontiev (Ed.), Lichnostnyi potentsial: struktura i diagnostika [Personal potential: Structure and diagnostics] (pp. 404-423). Moscow: Smysl.

Osin, E. N. (2007). Smysloutrata kak perezhivanie otchuzhdeniya: struktura i diagnostika [Loss of meaning as a feeling of alienation: structure and diagnostics] (Ph.D. dissertation, Lomonosov Moscow State University, Moscow).

Osin, E. N., \& Leontiev, D. A. (2008). Aprobatsiya russkoyazychnykh versii dvukh shkal ekspressotsenki sub"ektivnogo blagopoluchiya [Approbation of Russian versions the two scales for express-assessment of subjective well-being]. In Materialy III Vserossiiskogo Sotsiologicheskogo Kongressa [Proceedings of the III All-Russian Sociological Congress]. Moscow: Institute of Sociology of the Russian Academy of Sciences / Russian Society of Sociologists. Retrieved from http://publications.hse.ru/en/chapters/78753840 
Rasskazova, E. I., Bogomaz, S. A., Dorfman, L. Y., Leontiev, D. A., Neyaskina, Y. Y., Sulimina, O. V., \& Chetoshnikova, E. V. (2013). Psychometric characteristics of the Russian version of MMPI-2. Psikhologicheskie Issledovaniya, 6(29). Retrieved from http://psystudy.ru (in Russian)

Shumskiy, V. B. (2016). Ekzistentsialnaya psikhologia i psikhoterapia. Moscow: Urait.

Tabachnick, B. L., \& Fidell L. S. (2007). Using multivariate statistics (5th ed.). Boston, MA: Pearson Education.

Ukolova, E. M., Shumskiy, V. B., \& Osin, E. N. (2014). TEMIR - A test to measure existential motivations in interpersonal relationships: Factorial structure, reliability and validity. Existenzanalyse, 31(2), 8-13.

Yagiyaev, I. I., Osin, E. M., \& Gordeeva, T. O. (2015). Rosiis'komovna adaptatsiya metodiki zadovolenosti bazovikh psikhologichnykh potreb na ukranns'kii ta rosiis'kii vybirtsi [Russian-language adaptation of basic psychological needs satisfaction scales in Ukrainian and Russian samples]. In Visnik Kam'yanets'-Podil's'kogo natsional'nogo universitetu imeni Ivana Ogienka: Psikhologichni nauki [Herald of the I. Ogienko Kamyanets-Podil'sky National University: Psychological Sciences] (Iss. 7, pp. 182-190). Kamianets-Podilskyi: Medobori-2006. (in Ukranian)

Zaitsev, V. P. (1981). Variant psikhologicheskogo testa Mini-Mult [A version of a psychological test Mini-Mult]. Psikhologicheskii Zhurnal, 2(3), 118-123.

Żemojtel-Piotrowska, M., Piotrowski, J., Osin, E. N. Cieciuch, J., Adams, B. G., et al. (under review). Mental Health Continuum- Short Form: The structure and application for cross-cultural studies. Journal of Clinical Psychology.

Vladimir B. Shumsky - associate professor, Faculty of Social Sciences, School of Psychology, National Research University Higher School of Economics, Ph.D.

Research area: existential psychology, personality psychology, psychological counseling, psychotherapy.

E-mail: existenzanalyse@yandex.ru

Elena M. Ukolova - senior lecturer, Faculty of Social Sciences, School of Psychology, Department of Psychology of Personality, National Research University Higher School of Economics, Ph.D.

Research area: psychology of personality and individuality, the methodology of teaching psychology, existential psychology and psychotherapy, child and adolescent psychology and psychotherapy. E-mail: eukolova@hse.ru

Evgeny N. Osin - associate professor, Faculty of Social Sciences, School of Psychology, Leading Research Fellow, International Laboratory of Positive Psychology of Personality and Motivation, National Research University Higher School of Economics, Ph.D.

Research area: existential psychology, positive psychology, psychometrics.

E-mail: evgeny.n.osin@gmail.com

Yana D. Lupandina - master of psychology, specialist recruitment, OOO Price water house Coopers Advisory White Square Office Center.

Research area: existential psychology, psychological testing, staff assessment.

E-mail: yanalupandina@mail.ru 